\title{
Can Islamic banking revive Somalia's ailing economy?
}

\section{Mohammed Hersi Warsame ${ }^{\mathrm{a}^{*}}$, Yousif Abdelbagi Abdalla ${ }^{\mathrm{a}, \mathrm{b}}$ and Alhashmi Aboubaker Lasyoud ${ }^{\mathrm{a}, \mathrm{c}}$}

${ }^{a}$ College of Business administration, University of Sharjah, UAE

${ }^{b}$ School of Management Studies, University of Khartoum, Sudan

${ }^{c}$ Faculty of Economics and Political Science, Sabratha University, Libya

\section{H R O N I C L E}

Article history:
Received: January 5, 2021
Received in revised format:
January 262021
Accepted: March 30, 2021
Available online:
March 30, 2021
Keywords:
Central Bank of Somalia Hawala
Islamic Banks
Sharia-Compliant Finance

\section{Introduction}

Conflict-affected countries must undergo immense challenges for achieving financial stability and development (Collier et al., 2019). Somalia exemplifies the post-effect of conflict as it continues to bear its aftershock. Since 1991, Somalia has experienced tremendous instability and political turmoil for about two decades, from the occurrence of the civil war followed by the constant and intractable stagnation of its economy (Hoehne, 2019). The prolonged economic stagnation has affected the country's functions along with the absence of a legal and regulatory mechanism that further collapsed during the turmoil (Musse et al., 2019). In the absence of economic and financial regulators, the role of money transfer operators (MTO) emerged, which provided a channel to transfer money from the Somali Diasporas to their relatives within the country (The World Bank, 2016). Moreover, the cash transactions occurred using the mobile money service, which posed financial challenges due to alteration in the legislative regulations (Firestone et al., 2017). To overcome the risk, countries are suggested to form a financial institute. A considerable amount of economic literature stressed that sound financial systems could enhance economic progress and development (Ductor \& Grechyna, 2015; Kozarević et al., 2017). Such as, Alexander Hamilton, one of the founding fathers of America, stated: "Banks were the happiest engines that ever were invented." However, some developmental economists ignored the role of financial systems for many decades as they focused more on other policy areas as far as economic development is concerned, but empirical studies found a statistically significant correlation between financial systems development and economic growth". However, recent literature has prioritized financial inclusion with an institute based on its positive financial outcomes. For instance, the Global Financial Development Report (GFDR) report of the World Bank (2014) demonstrates that about $2 / 3^{\text {rd }}$ of the financial agencies are inclined to promote Islamic financial inclusion, due to its established efficiency of producing desirable economic outcomes. Surprisingly, both Muslim and non-Muslim countries

* Corresponding author.

E-mail address: mwarsame@sharjah.ac.ae (M. H. Warsame)

(C) 2021 by the authors; licensee Growing Science, Canada doi: $10.5267 /$ j.ac.2021.4.027 
are encouraging the inclusion of Islamic financial practices which globally accounts for $\$ 2$ trillion assets with an estimated growth of $15 \%$ to $20 \%$, demonstrating its resilience and growth. Shen (2017) showed that Shariah-based financial services and products are being offered in about fifty Muslim and non-Muslim states, based on its recognition as an economic stimulator. Hussein, Shahmarodi and Turk (2016) resonate that this is due to its integrated principles of equity participation and ownership. Moreover, it also absorbs the shocks and is relatively resistant because of its risk-sharing principle. Since Somalia is vulnerable to financial shocks and has a stagnant economy for about 20 years, the study aims to assess whether Islamic banking can revive Somalia's ailing economy or not.

\section{Statement of the Problem and Research Objectives}

Somalia gained independence in 1960 from both British and Italian colonizers, but due to prolonged conflicts with neighbouring countries and poor governance, it is one of the poorest countries in the world, and the population is heavily dependent on foreign aid (Muktar Adan, 2017). Despite it, the country allocates its $70 \%$ of its budget to security sectors while only $30 \%$ to the development programs (Muktar Adan, 2017). An articulate and synchronized domestic workplace has been prevented in Somalia due to the presence of political turbulence and violence (African Fixed Income Guidebook, 2006) (African Fixed Income Guidebook, 2006). Limited commercial banking services have been offered by the central banks in Bosasso and Hargeisa to create an unintended conflict of interest with their contribution as treasurers of their respective regional governments. However, the country has neither commercial nor the central monetary authority banks (Amisom report, 2015). Moreover, the Somali money transfer operations are under risk due to disruptions in regulation in both the UK and the USA, such as a change in regulation has led British bank Barclays to close almost 200 accounts, following no explanation (Keatinge, 2014). This has hindered the transactions of the money to the Somali, which has an adverse impact on the humanitarian crisis in Somalia (SWIFT, 2016). To overcome this situation, inclusion with the financial sector is required particularly with Islamic banking system (also referred to as Shari'ah compliant finance institution) (Hussein et al., 2015). Evidence from the literature also presents that instigation of Islamic financial banking has proven as a sturdy tool for emerging and underdeveloped countries. Such as research of Razman, and Safian (2019) on Malaysia economy recognized Islamic banking as a mode for debt recovery. Likewise, Ali et al. (2019) on Pakistan have shown that it reduces the credit risk while simultaneously escalating its performance. Analyzing the economy of Indonesia, Malaysia, and Bangladesh, Pramanik et al. (2015) concluded that Islamic banking facilitating the growth of the countries has alleviated poverty to a significant margin. Similar performance outcomes and economic progress were stated for Indonesia (Abdul-Majeed Alaro \& Alalubosa, 2019), Latvia (Saksonova \& Kuzmina-Merlino, 2017), Bangladesh (Islam \& Sultana, 2019), Taiwan (Puaschunder, 2019) and Tanzania (Omar \& Yusoff, 2019). Given this, the inclusion of the financial sector can help revive their economic conditions, and can integrate the country's efforts to bridge his shortcomings for progressing their economy and proving their self-sustained expansions (Warsame, 2009). Notably, the volatile environment of Somalia combined with the absence of a financial sector, required instigation of the effective policies which can assist Islamic banks to expand and penetrate in the economy, raising its prosperity prospects, where Malaysia stands as a strong example (Musse, 2015). Therefore, an Islamic bank is believed to revive the economy of the country and aid it in overcoming the economic pitfalls. Furthermore, Wilson (2016) further promotes the study to evaluate whether the inclusion of the Islamic financial banking can promote its sustainable economic development.

The development of the strong economy and revival of its economic stance is also critical as it allows the country to sustain its existence. Mvukiyehe and Samii (2018) state economic recovery as the peacebuilding tool; it also cites the study of Collier et al. (2008) which found that $10 \%$ economic rate reduces the conflict risk from $42 \%$ to $27 \%$ for another ten years. Similarly, in case, a 5\% decline in economic growth occurs, the conflict risk increases to 50\% for the following years (Wilson, 2016). This makes the revival integral for Somalia, emphasizing the evaluation of Islamic banking in the economic revival of Somalia. A clear commercial banking sector will be indispensable as Somalia struggles to redevelop its devastated economy. This paper seeks to establish the prospects of establishing a Sharia-compliant financial system in Somalia and the cumulative effect that the newly established Islamic banks would have on the country's economic growth. The main research objective of this study is to assess the prospects of establishing Islamic banking in Somalia and the role it can play in reviving the country's ailing economy. Following research questions are developed to address the aforementioned concerns:

1. To what extent, Somalia establishes its banking and financial system for reviving its financial and political infrastructure?

2. What is the current financial and banking status of Somalia and its association with its political and economic stability?

3. How law and order of Somalia address the political and financial chaos of its banking system?

4. How Sharia-compliant finance and banking models in Somalia revive the financial system of Somalia?

\section{Material and Methods}

\subsection{Study Design}

The purpose of this study was to examine the prospects of Islamic Banking in Somalia`s Economy; its challenges and opportunities. For this, a quantitative study design was adopted. The rationale behind the selection of this particular design is based 
on its efficiency for producing relevant, sturdy, and easy to comprehend results. Previous studies on a similar subject have also established its efficiency, which promoted its selection (Gadzo et al., 2019; Mansour et al., 2016).

Study Sample

The population of the study constitutes financial literature about Somalis. These were recruited using purposive sampling based on the inclusion criteria which required them to be financially literate, understand the political environment of Somalia, had firm Somali roots and were resided in the United Kingdom (UK) or United Arab Emirates (UAE). The study sample size $(N=100)$ was a good starting point in carrying out path modeling (Burmeister and Aitken, 2012; Hoyle, 1995). This research had four main research questions as the forthcoming paragraphs explain. In this survey, they used four latent variables (factors), and ten manifest variables (latent variables), based on a 5-point Likert scale.

\section{Data Analysis}

The researcher used Structural Equation Modeling (SEM) - Partial Least Squares (PLS), a multivariate analysis which focuses on the analysis of variance using SmartPLS (Ringle et al., 2015). The study has used a reflective measurement scale as the determined indicators were highly correlated and interchangeable. The PLS Algorithm settings used include Path Weighting Scheme, Mean 0, Variance 1, 1000 Maximum Iterations, 1.0E-7 About Criterion, and Initial Weights of 1 . The reliability and validity of the indicators were thoroughly examined, and their outer loadings, composite reliability, Average Variance Extracted (AVE) and its square root reported. Consequently, IBM SPSS version 22 was used to perform multiple regression analysis to obtain the tolerance, Variance Inflation Factor (VIF), and the coefficient values (Table 1).

\section{Table 1}

Latent and the manifest Variables used in the study

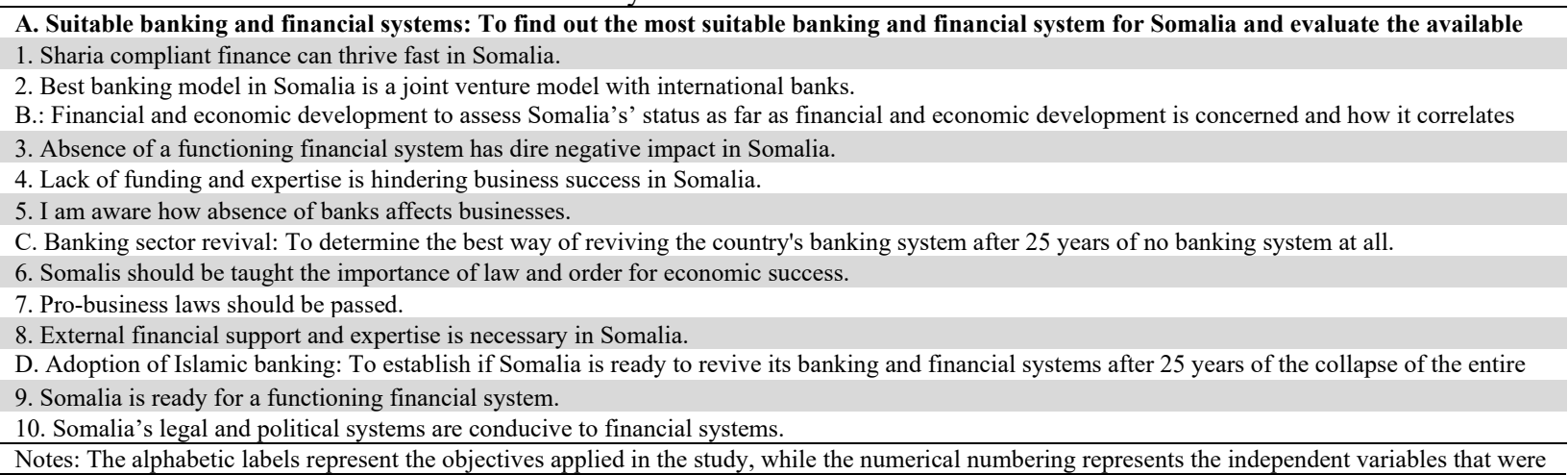

\section{Results}

\section{Assessing the structural model: Target endogenous variable variance}

The coefficient of determination, $R^{2}$, was 0.862 for the satisfaction endogenous latent variable. Concerning the path model, Chin (1998) states that endogenous latent variables $R^{2}$ values of $0.67,0.33$, or 0.19 are described as substantial, moderate, or weak, respectively. This meant that financial and economic development, banking sector revival, and adoption of Islamic banking substantially explain $86.2 \%$ of the variance on suitable banking and financial systems in Somalia.

\section{Inner model path coefficient sizes and significance}

The inner model suggested that banking sector revival had the strongest effect on the suitable banking and financial systems in Somalia (0.932), while adoption of Islamic banking and financial and economic development had the least effects at 0.046 and -0.015 , respectively. The hypothesized path relationships between banking sector revival and suitable banking and financial systems were statistically significant. Thus, it is concluded that banking sector revival was substantial, strong predictors of suitable banking and financial systems to be undertaken by the Somalia government. The hypothesized path relationships on the adoption of Islamic banking and financial and economic development were not statistically significant, meaning they were very poor predictors of Islamic banking in Somali. See Figure 1 for the $R^{2}$ values inside the circles, and the path coefficients on arrows.

\section{Outer model loadings}

The outcome of the study estimation was stable because it had assigned 1000 maximum iterations in the model, and the achieved algorithm converged only after 87 iterations. A PLS-SEM technical note by (Wong, 2013), suggests that if the PLS- 
SEM algorithm does not converge in less than 300 iterations, then the data is abnormal and requires further investigations. Thus, it is concluded that the model estimation was good.

Indicator reliability

The study established the reliability and validity of the latent variables on the structural model. The composite reliability had values larger than 0.6; thus, high levels of internal consistency were demonstrated among financial and economic development (0.876), banking sector revival (0.685), adoption of Islamic banking (0.659) and suitable banking and financial systems (0.674) reflective latent variables. Bagozzi and Yi, (1988); Hair et al. (2012) suggest that the internal consistency reliability of 0.6 or higher in exploratory research is acceptable. The internal consistency reliability should be above 0.7 as recommended by Nunnally and Bernstein (1994). Thus, it can be stated that the study research questions had high internal consistency values and thus were satisfactory. Henseler et al. (2009) propose that a latent variable should explain at least 50\% of the indicator's variances. The results showed that only two indicator variances; the sharia-compliant finance could thrive fast in Somalia, and the Somalis should be taught the importance of law and order for economic success were below 50\% (Fig. 1).

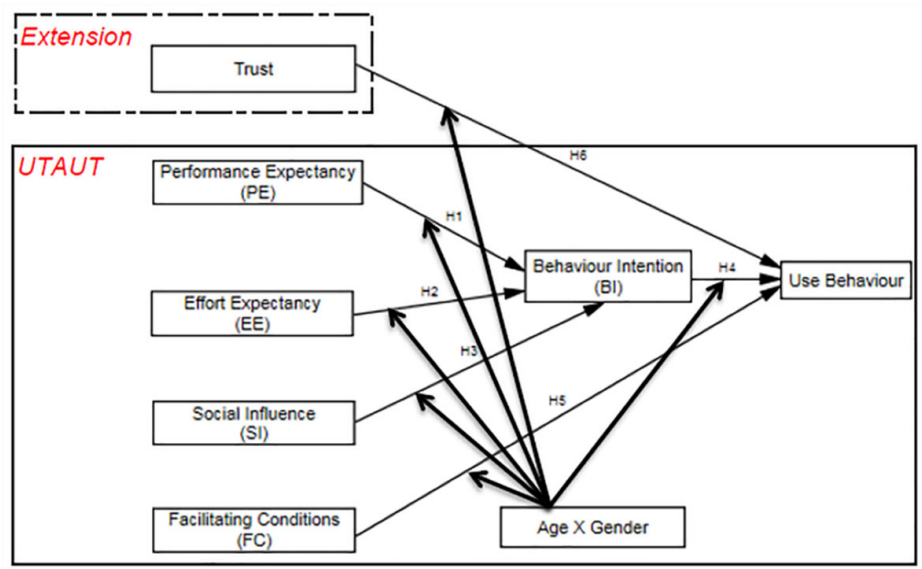

Convergent validity

Fig. 1. The proposed method

The Average Variance Extracted (AVE) was evaluated, and all latent variables were greater than the acceptable threshold of 0.5 (Table 2), thus confirming the validity of the findings. Literature by Bagozzi and Yi (1988); Götz et al. (2009) suggests that the convergent validity of 0.5 or higher in exploratory research is acceptable for convergent validity testing (Table 2 ).

Table 2

$\underline{\text { Results Summary for Reflective Outer Models }}$

\begin{tabular}{|c|c|c|c|c|c|}
\hline Latent variable & Indicators & Loadings (L) & $\begin{array}{l}\text { Indicator Reliability } \\
\text { (L2) }\end{array}$ & $\begin{array}{l}\text { Composite Reliabil- } \\
\text { ity }\end{array}$ & AVE \\
\hline Suitable banking and financial systems & 1 & -0.306 & -0.093 & \multirow[t]{2}{*}{0.674} & \multirow[t]{2}{*}{0.61} \\
\hline \multirow{3}{*}{ Financial and economic development } & 2 & 0.928 & 0.861 & & \\
\hline & 3 & 0.926 & 0.857 & \multirow[t]{2}{*}{0.876} & \multirow[t]{3}{*}{0.706} \\
\hline & 4 & 0.908 & 0.825 & & \\
\hline \multirow{3}{*}{ Banking sector revival } & 5 & 0.66 & 0.436 & \multirow{3}{*}{0.685} & \\
\hline & 6 & -0.235 & -0.055 & & \multirow[t]{2}{*}{0.596} \\
\hline & 7 & 0.934 & 0.872 & & \\
\hline \multirow{3}{*}{ Adoption of Islamic banking } & 8 & 0.927 & 0.859 & \multirow{3}{*}{0.659} & \multirow{3}{*}{0.504} \\
\hline & 9 & 0.849 & 0.721 & & \\
\hline & 10 & 0.536 & 0.287 & & \\
\hline
\end{tabular}

\section{Discriminant validity}

Fornell and Larcker (1981) recommend that the square root of AVE of each latent variable should be higher than the correlation among the latent variables. The values were compared against the latent variable correlation results from the results. The discriminant values are in bold, while the correlation values are not. The discriminant values were found to be larger than the correlation values thus indicating that the discriminant validity was well established (Table 3). 
Table 3

Fornell-Lacker criterion analysis for checking discriminant validity

\begin{tabular}{lllll}
\hline & $\begin{array}{l}\text { Adoption of Is- } \\
\text { lamic banking }\end{array}$ & $\begin{array}{l}\text { Banking sec- } \\
\text { tor revival }\end{array}$ & $\begin{array}{l}\text { Financial and economic } \\
\text { development }\end{array}$ & $\begin{array}{l}\text { Suitable banking and finan- } \\
\text { cial systems }\end{array}$ \\
\hline Adoption of Islamic banking & 0.709 & & & \\
Banking sector revival & -0.124 & 0.772 & & 0.84 \\
Financial and economic development & -0.125 & -0.028 & -0.047 & 0.781 \\
\hline Suitable banking and financial sys- & -0.067 & 0.927 & & \\
\hline
\end{tabular}

If the HTMT value is below 1, Henseler et al. (2015) have proposed that discriminant validity can be developed between economic two associated constructs. Therefore, discriminant validity was established between financial and economic development and adoption of Islamic banking, financial and economic development, and banking sector revival, suitable banking and financial systems and financial and economic development (Table 4).

Table 4

Heterotrait-Monotrait Ratio (HTMT) Analysis for Checking Discriminant Validity

\begin{tabular}{llll}
\hline & $\begin{array}{l}\text { Adoption of Islamic } \\
\text { banking }\end{array}$ & $\begin{array}{l}\text { Banking sector } \\
\text { revival }\end{array}$ & $\begin{array}{l}\text { Financial and economic } \\
\text { development }\end{array}$ \\
\hline Adoption of Islamic banking & & & $\begin{array}{l}\text { Suitable banking and finan- } \\
\text { cial systems }\end{array}$ \\
Banking sector revival & 1.173 & & \\
Financial and economic development & 0.567 & 0.09 & 0.114 \\
\hline Suitable banking and financial systems & 1.11 & 1.528 & \\
\hline
\end{tabular}

\section{Multicollinearity Assessment}

The latent variable scores from the PLS output were analyzed to access collinearity issues of the model. The latent variable scores from the PLS algorithm were used to run the linear regression analysis using SPSS version 22 (IBM Corp, 2013). Adoption of Islamic banking, banking sector revival and financial and economic development were configured as the independent predictor latent variables, while suitable banking and financial systems were configured as the dependent variable. Hair et al. (2011) have proposed that the collinearity problem can be avoided by having a VIF of 5 or lower (Table 5). It is concluded that the data did not have multi-collinearity problems.

Table 5

Linear Regression Unstandardized Coefficients and Collinearity

\begin{tabular}{|c|c|c|c|c|c|c|c|c|c|}
\hline \multirow[b]{3}{*}{ Model } & \multicolumn{5}{|c|}{ Coefficients(a) } & \multirow[b]{2}{*}{$95 \% \mathrm{CI}$} & \multirow{2}{*}{\multicolumn{2}{|c|}{ CS }} & \multirow[b]{3}{*}{ VIF } \\
\hline & \multicolumn{2}{|c|}{ Ucoeff } & \multirow{2}{*}{$\begin{array}{c}\text { SCoeff } \\
\text { Beta } \\
\end{array}$} & \multirow[t]{2}{*}{$\mathbf{T}$} & \multirow[t]{2}{*}{$\mathbf{p}$} & & & & \\
\hline & B & SE & & & & LB & UB & Tol & \\
\hline (Constant) & 0.016 & 0.041 & & 0.397 & 0.692 & -0.066 & 0.099 & & \\
\hline 1). Adoption of Islamic banking & 0.033 & 0.042 & 0.033 & 0.79 & 0.431 & -0.05 & 0.117 & 0.968 & 1.033 \\
\hline 2). Banking sector revival & 0.922 & 0.042 & 0.916 & 22.018 & $<0.001$ & 0.838 & 1.005 & 0.983 & 1.017 \\
\hline 3). Financial and economic development & -0.034 & 0.042 & -0.034 & -0.806 & 0.422 & -0.117 & 0.049 & 0.983 & 1.018 \\
\hline
\end{tabular}

\section{Effect size Cohen's f}

The effect size was calculated using Cohen's (1988) $f^{2}$ test to assess the magnitude of the relationship between the latent variables;

$$
f^{2}=R_{\text {Included }}-R^{2} \text { Excluded } /\left(1-R^{2} \text { Included }\right)(\text { Henseler et al., 2009) }
$$

The Cohen's $f^{2}$ value was 0.96 , meaning that there was a large effect on the relationships between suitable banking and financial systems and banking sector revival. A significant association between the predictor variables and dependent variable has been obtained using the ANOVA test $\mathrm{F}(3,96)=163.78 ; \mathrm{p}<.001$.

\section{Discussion}


Prior to 1991, when the governing regime collapsed, the Somali Development Bank, the Somali Commercial Bank, and the Commercial and Savings Bank of Somalia are included in the three major banks in Somalia (Powell and Al-Hallaq, 2006).

To what extent, Somalia establish its banking and financial system for reviving its financial and political infrastructure? The hypothesis was tested using three independent variables, namely; absence of a functioning financial system, lack of funding and expertise, and effect of bank absence on businesses. The findings revealed that absence of a functioning financial system has a dire negative impact in Somalia, lack of funding and expertise is hindering business success in Somalia, while the effect of bank absence on businesses was well-recognized. The hypothesized path on financial and economic development -0.015 , was not statistically significant. This meant that their impact was not much on their overall influence on the suitability of banking systems revival in Somalia.

What is the current financial and banking status of Somalia and its association with its political and economic stability? The hypothesis was tested using two independent variables, namely; Somalia is ready for a functioning financial system, and Somalia's legal and political systems are conducive to financial systems. The hypothesized path on the adoption of Islamic banking was 0.046 . Their measures were good, but they did not indicate any significant influence. This meant that their impact was not much on their overall influence on the suitability of banking systems revival in Somalia.

How law and order of Somalia address the political and financial chaos of its banking system?

This hypothesis was tested using three independent variables namely; Somalis should be taught the importance of law and order for economic success, Pro-business laws should be passed, and external financial support and expertise is necessary for Somalia. Their measures were good and indicated a significant influence on suitable banking and financial systems in Somalia. The hypothesized path relationship on banking sector revival 0.932 was statistically significant, meaning that it was an excellent measure of suitable banking and financial systems in Somalia. This meant that their influence was much on their overall influence on the suitability of banking systems revival in Somalia. The passing of pro-business laws 0.934 , the external financial support, and expertise 0.927 were found to be the best measures of reviving Somalia's banking system after 25 years of no banking system. These findings agree with Levine and Sara (1998) governments are pressurized by foreign banks for enhancing supervision and regulation, catalyze domestic reform, increase transparency, and hence pro-business laws and the external financial support and expertise would be the best measures of reviving Somalia's banking system. Most Somalis felt that being taught the importance of law and order -0.235 was not a priority measure of reviving Somalia's banking system after 25 years of no banking system.

\section{How Sharia-compliant finance and banking model in Somalia revive the financial system of Somalia?}

This hypothesis was tested using two independent variables, namely; Sharia-compliant finance can thrive fast in Somalia, and the best banking model in Somalia is a joint venture model with international banks. In this survey, it is found that a joint venture bank model with international banks with a significant loading value of 0.928 was a very good measure of suitable banking and financial systems that can thrive well in Somalia. The finding agrees with Claessens et al. (2008) that greater financial stability is resulted when foreign banks increase access to financial services, improve the financial and economic performance of their borrowers, and add to domestic competition. The finding also agrees with Levine (1998) about the consensus among development economists that both transparent legal systems and well-functioning financial systems are indispensable ingredients for economic growth. However, Sharia-compliant finance had a weak negative response -0.306, meaning that most Somalis were not yet convinced much that Sharia-compliant banks alone could thrive on their own in Somalia. The finding is in line with African Fixed Income Guidebook, (2006) and World Bank (2012) that remittance companies transfer funds into Somalia by using Hawala system. This means that Somalis have bonded well and built their trust in Hawala systems.

\section{Implications}

The findings of the study suggest that in order for Somalia to revive its banking sector after 25 years of collapse, the Somalia government would need to introduce pro-business laws. This can be achieved by the outsourcing of external financial support and expertise as a joint venture model with international banks. Along with it, it needs to recruit robust human capital with sound financial knowledge and capabilities for effective decision making, which stems from the basic principles of Islamic finance. Moreover, to strengthen the sector, the academic sector should also be engaged by introducing various research and development initiatives. A training program can also be initiated for enhancing the professional competence and literacy to the Islamic banking system. It also suggests that efforts must be instigated for enhancing the environmental opportunities which are suitable for the prosperity of the Islamic banking in Somalia.

Another factor which can improve the status of the banks in Somalia is their development for attaining competitive advantage. This can be achieved through market penetration as well as customer engagement. Similarly, the financial opportunity prospects should be optimized by engaging the Somalia Diasporas who have financial funds and ideas. Moreover, the legislative body should be strengthened to formulate a policy that overcomes the issue related to exposures to liquidity risk. Accordingly, the policies should be strategized for improving the financial status where the government should initially screen customers 
prior to engagement with the business with them along with the national identity. Also, the transparency in the business operations for the banking sector should be introduced for enhancing banks efficiency and quality while also overcoming its operational difficulties. Implementation of this suggestion can help leverage the Somalian economy and progress its economy.

\section{Conclusion}

This study had four research objectives and eleven related independent variables to these four research objectives. For each objective, a null hypothesis $\left(\mathrm{H}_{\mathrm{O}}\right)$ and an alternative hypothesis $\left(\mathrm{H}_{\mathrm{A}}\right)$ was developed to test the same. All the related hypotheses of these objectives were tested, and as a result of the various statistical tests, some of them were rejected, while others were accepted as it can be noted in the analysis section of the document. All relevant descriptive statistics, as well as inferential statistics, were conducted on the collected survey data, and certain conclusions were drawn from the results as presented in this section. Fortunately, the four research objectives were achieved by testing their related independent variables, and major findings were clearly presented in the analysis section of this research document, but the summary is depicted here. The research concluded that Somalia is ready to revive its banking and financial systems after 25 years of the collapse of the entire financial and political infrastructure. Furthermore, the test results of the study hypotheses indicate that Somali business people with knowledge of Somalia's socio-economic landscape are aware that the absence of banks adversely affects business success in Somalia by confirming through the data analysis that the absence of functioning financial systems has a dire negative impact for Somalia businesses. Also, the research found that the majority of respondents agreed that external financial support and expertise is necessary in Somalia for business success, like many other parts of the world. However, a significant number of respondents have also emphasized the importance of law and order for economic success. Hence, they believe Somalis should be taught the importance of law and order for economic success. Finally, the research revealed that most respondents believe that Sharia-compliant finance can thrive fast in Somalia, and they were of the view that the best banking model in Somalia is a joint venture model with international banks setting up branches in the country. It is worth noting that the majority of respondents agreed that Standalone new banks in Somalia have fewer chances of success due to the lack of expertise among the indigenous population.

\section{Acknowledgements}

The author is thankful to all the associated personnel, who contributed for this study. This research is funded by the Deanship of Scientific Research in Zarqa University / Jordan

\section{References}

Alaro, A. A. M., \& Alalubosa, A. H. (2019). Potential of Shar̄̄'ah compliant microfinance in alleviating poverty in Nigeria. International Journal of Islamic and Middle Eastern Finance and Management, 12(1), 115-129. https://doi.org/10.1108/imefm-01-2017-0021

African Fixed Income Guidebook. (2006), State banks, institutions, and financial development. Stockholm: European Economic Association.

Ali, A., Zulkhibri, M., \& Kishwar, T. (2019). Credit Risk, Bank Performance, and Islamic Banking: Evidence from Pakistan. In Islamic Finance, Risk-Sharing and Macroeconomic Stability (pp. 171-189). Palgrave Macmillan, Cham. https://doi.org/10.1007/978-3-030-05225-6_9

Bagozzi, R., \& Yi, Y. (1988). On the evaluation of structural equation model. Journal of the Academy of Marketing Science, 16(1), 74-94. https://doi.org/10.1177/009207038801600107

Burmeister, E., \& Aitken, L.M. (2012). Sample size: How many is enough?. Australian Critical Care, 25(4), $271-274$. https://doi.org/10.1016/j.aucc.2012.07.002

Claessens, S., Feijen, E., \& Laeven, L. (2008). Political connections and preferential access to finance: The role of campaign contributions. Journal of Financial Economics, 88(3), 554-580. https://doi.org/10.1016/j.jfineco.2006.11.003

Collier, P., Gregory, N., \& Ragoussis, A. (2019). Pioneering Firms in Fragile and Conflict-Affected States: Why and How Development Finance Institutions Should Support Them. World Bank Policy Research Working Paper, 8774. https://doi.org/10.1596/1813-9450-8774

Collier, P., Hoeffler, A., \& Söderbom, M. (2008). Post-conflict risk. Journal of Peace Research, 45(4), 461-478. https://doi.org/10.1177/0022343308091356

Ductor, L., \& Grechyna, D. (2015). Financial development, real sector, and economic growth. International Review of Economics and Finance, 37, 393-405. https://doi.org/10.1016/j.iref.2015.01.001

Firestone, R., Kelly, T., \& Refon, A. (2017). A game changer - the prospects and pitfalls of mobile money in Somalia. Available at: https://blogs.worldbank.org/nasikiliza/a-game-changer-the-prospects-and-pitfalls-of-mobile-money-in-somalia

Fornell, C., \& Larcker, D. (1981). Evaluating structural equation models with unobservable variables and measurement error", Journal of Marketing Research, 18(1), 39-50. https://doi.org/10.1177/002224378101800104

Gadzo, S.G., Kportorgbi, H.K., \& Gatsi, J.G. (2019). Credit risk and operational risk on financial performance of universal banks in Ghana: A partial least squared structural equation model (PLS SEM) approach. Cogent Economics \& Finance, 7(1), 1589406. https://doi.org/10.1080/23322039.2019.1589406 
Götz, O., Liehr-Gobbers, K., \& Krafft, M. (2010). Evaluation of structural equation models using the partial least squares (PLS) approach. In Handbook of partial least squares (pp. 691-711). Springer, Berlin, Heidelberg. https://doi.org/10.1007/978-3-540-32827-8_30

Hair, J., Ringle, C., \& Sarstedt, M. (2011). PLS-SEM: Indeed a silver bullet. Journal of Marketing Theory and Practice, 19(2), 139-151. https://doi.org/10.2753/mtp1069-6679190202

Hair, J., Sarstedt, M., Ringle, C., \& Mena, J. (2012). An assessment of the use of partial least squares structural equation modeling in marketing research. Journal of the Academy of Marketing Science, 40(3), 414-433. https://doi.org/10.1007/s11747-011-0261-6

Henseler, J., Ringle, C., \& Sinkovics, R. (2009). The use of partial least squares path modeling in International marketing. New Challenges to International Marketing Advances in International Marketing. Emerald Group Publishing Limited. https://doi.org/10.1108/s1474-7979(2009)0000020014

Henseler, J., Ringle, C.M., \& Sarstedt, M. (2015). A new criterion for assessing discriminant validity in variance-based structural equation modeling. Journal of the Academy of Marketing Science, 43(1), 115-135. https://doi.org/10.1007/s11747014-0403-8

Hoehne, M.V. (2019). Against the grain: Somaliland's secession from Somalia. In Secessionism in African Politics (pp. 229261). Palgrave Macmillan, Cham. https://doi.org/10.1007/978-3-319-90206-7_9

Hoyle, R.H. (1995). Structural Equation Modeling. Thousand Oaks, CA: SAGE Püblication.

IBM Corp. (2013). IBM SPSS Statistics for Windows, Version 22.0. Armonk. New York: IBM Corp.

Islam, S., \& Sultana, T. (2019). Practice of Islamic Financial Management in Bangladesh: Evidence from Islamic Banks. International Journal of Islamic Banking and Finance Research, 3(1), 1-12.

Keatinge, T. (2014). Uncharitable behavior. Demos, 31. Available at: https://www.demos.co.uk/files/ DEMOSuncharitablebehaviourREPORT.pdf

Kozarević, E., Polić, N., \& Perić, A. (2017). Financial system development progress in Western Balkans. Banks and Bank Systems, 12(2), 7-19. https://doi.org/10.21511/bbs.12(2).2017.01

Mansour, W., Hajlaoui, L. L., Abdulkarim, F., \& Nassief, M. (2016). Trust crisis in Islamic banking: empirical evidence using structural equations modeling. International Journal of Business, 21(2), 157.

Muktar Adan, A.K. (2017). Overcoming Challenges in an Unrecognized Economy: Experience from Somaliland", American International Journal of Contemporary Research, 7.

Musse, A.M., Ab Rashid, R., \& Zainol, Z. (2019). The Emergence of Islamic Banks in Somalia in the Post-Conflict Era: Prospects and Challenges. Indian-Pacific Journal of Accounting and Finance, 3(1), 41-49.

Mvukiyehe, E., \& Samii, C. (2018). Peacekeeping and development in fragile states: micro-level evidence from Liberia. The World Bank.

Nunnally, J., \& Bernstein, I. (1994). Psychometrictheory, $3^{\text {rd }}$ Ed., New York: McGraw-Hill.

Omar, H.H., \& Yusoff, M.E. (2019). Central Bank Impact on Practicing Mudarabah Financing in Islamic Banks: THE CASE OF Tanzania.

Powell, N., \& Al-Hallaq, S. (2006). The role of Islamic banks in economic growth: The case of Jordan. In Islamic Finance and Economic Development. Chipenham and Eastbourn: Palgrave MacMillan.

Pramanik, A.H., Mohammed, M.O., Haneef, M.A., Amin, F.M., Aliyu, A.D., Dabour, N., \& Bağc1, K. (2015). Integration of Waqf and Islamic Microfinance for Poverty Reduction: Case Studies of Malaysia, Indonesia and Bangladesh. The Statistical, Economic and Social Research and Training Centre for Islamic Countries (SESRIC) and International Islamic University Malaysia (IIUM), Gombak, Kuala Lumpur.

Puaschunder, J.M. (2019). The History of Ethical, Environmental, Social, and Governance-Oriented Investments as a Key to Sustainable Prosperity in the Finance World", Public Integrity, 21, 161-181. https://doi.org/10.1080/10999922.2018.1439563

Razman, A.A., \& Safian, Y.H.M. (2019). Current Practice of Debt Recovery Methods in Islamic Banks in Malaysia. AlQanatir: International Journal of Islamic Studies, 13(23), 93-110.

Ringle, C.M., Wende, S., \& Becker, J.M. (2015). SmartPLS 3. Bönningstedt: SmartPLS.

Saksonova, S., \& Kuzmina-Merlino, I. (2017). Fintech as Financial Innovation-The Possibilities and Problems of Implementation. European Research Studies, 20(3A), 961.

Shen, N.M. (2017). Growing the Islamic Banking Business. The Malaysian Reserve. Available at: https://themalaysianreserve.com/2017/08/21/growingislamic-banking-business/.

SWIFT. (2016), Addressing the Unintended Consequences of De-risking - Focus on Africa. Available at: https:/www.swift.com/insights/news/addressing-theunintended-consequences-of-de-risking

The World Bank. (2016), World Bank Makes Progress to support Remittance Flows to Somalia. Mogadishu: The World Report. Available at: http://www.worldbank.org/en/news/press-release/2016/06/10/world-bank-makes-progress-to-support-remittance-flows-to-somalia

Warsame, M.H. (2009). The role of Islamic finance in tackling financial exclusion in the UK (Ph.D Thesis).

Wilson, T. (2016). Economic recovery in Somalia. Bildhaan: An International Journal of Somali Studies, $15(1), 9$.

Wong, K.K. (2013). Partial Least Square structural equation modeling (PLS-SEM) techniques using SmartPLS. Marketing Bulletin, 24(1), 1-32. 
(C) 2021 by the authors; licensee Growing Science, Canada. This is an open access article distributed under the terms and conditions of the Creative Commons Attribution (CC-BY) license (http://creativecommons.org/licenses/by/4.0/). 